\title{
Effect of Climate and Habitat on Morphological Characteristics and Fruit Production of Picralima Nitida (Stapf) in West Africa
}

\section{Ghislain Comlan AKABASSI ( $\square$ cgakabassi@gmail.com )}

University of Abomey Faculty of Agricultural Sciences: Universite d'Abomey-Calavi Faculte des Sciences Agronomiques https://orcid.org/0000-0003-4449-8421

\section{Elie Antoine Padonou}

University of Agriculture of Kétou: Universite Nationale d'Agriculture

Achille Ephrem Assogbadjo

University of Abomey-Calavi: Universite d'Abomey-Calavi

Noël Zirihi Guede

University of Felix Houphouet-Boigny: Universite Felix Houphouet-Boigny

\section{Research Article}

Keywords: Picralimanitida, Climaticzones, Morphologicalvariabilities, habitattype,

Physiochemicalcharacteristics, Soiltypes.

Posted Date: October 19th, 2021

DOI: https://doi.org/10.21203/rs.3.rs-878443/v1

License: (c) (1) This work is licensed under a Creative Commons Attribution 4.0 International License. Read Full License 


\section{Abstract}

Picralima nitida is an important African medicinal plant species used in pharmaceutical industries and traditional medicine to treat several diseases. Despite its importance, the species faces conservation problem. This study evaluated the effect of climate and habitat on morphological characteristics and fruit production of $P$. nitida. A total of 132 fruiting trees was randomly sampled from three habitat types (home gardens, botanical garden and natural forest) and three soils (Nitisols, Arenosols and Acrisols) in Dahomey Gap and Guineo-Congolese zone. A total of 5 morphological traits and fruit production were recorded per tree to describe the relationship between morphological determinism of the species and climate. Pearson correlation was performed to identify the suitable habitat type in each climatic zone. Harmonized World Soil Database was used to determine physicochemical characteristics of the soil types on which the species occurred. Results revealed that the climatic zones $(p<0.001)$ and habitat types $(p<0.0001)$ influenced significantly the morphological characteristics and fruit production of $P$. nitida. High trees with more number of fruits were observed in home gardens on acid soils (Nitisols ( $\mathrm{pH}$ : 5) and Arenosols (pH: 5.3)) in Dahomey Gap. In Guineo-Congolese zone, the species was more present in natural forest on acid Acrisols ( $\mathrm{pH}: 5)$.

\section{Introduction}

Picralima nitida (Stapf) T. Durand \& H. Durand is one of the endangered medicinal species across all its distribution range mainly in Dahomey Gap (DG, Betti 2004; Gbadamosi 2014; Akabassi et al. 2017). It is a forest species more present in Guineo-Congolese (GC) region (Erharuyi et al. 2014; Matig et al. 2006). It is a very useful species for African local peoples because of its high medicinal potential $(10,17)$. In almost all of its distribution areas (DG, GC), the plant has high priority in the treatment of diseases such as malaria, diabetes, infectious diseases, tonsillitis, cancer, etc. (Adjanohoun et al. 1996 ; Aguwa et al. 2001 ; Teugwa et al. 2013 ; Holaly et al. 2015 ; Akabassi et al. 2017). Despite its importance, the species faces serious problems of conservation in the different climatic zones where it occurs. In the GC region, it occurs only in the wild with a threat of extinction (Gbadamosi 2014). It is the first critically endangered species among the four species used by the indigenous populations of the eastern region of Cameroon for the typhoid fever treatment (Betti 2004). The species is quasi-absent in wild in DG but with occurrence of few isolated individuals in home gardens (Betti 2004).

Climate is one of the most important environmental factors affecting the physiology and ecology of plants. The climate variability and alteration of biogeochemical cycles can alter the species environmental determinism, affecting firstly their physiology, then their phenology and ultimately their distribution (Parmesan 2006). The main climate variables that affect the life and physiology of plants are light, temperature and precipitation (Jamieson et al. 2012). The action of each of these variables influences the productivity of the plant species. Climate therefore has important ecological consequences for plant species interactions that occur across multiple trophic levels. In addition to climate, soil also affect the morphological variations of the forest species (Chadare et al. 2008). Climate and soil are 
therefore important for assessing the production and the qualitative value of the forest species (Assogbadjo et al. 2012).

In DG, in addition to climate, most of the medicinal plant species are threatened because of the small size of the relict forests and the human pressure (Neuenschwander et al. (2011). Traditional agroforestry systems are considered as the second most important resource for the conservation of the threatened forest species (Idohou et al. 2014; Salako et al. 2014).

In contrary to other non-timber forest products (NTFPs) used for medicinal purposes, $P$. nitida has not yet attracted the attention of scientists in the field of domestication and/or conservation (Yakeu 2012). The studies performed on P. nitida concerned the effect of Watering Regimes and Water Quantity on the Early Seedling Growth (Gbadamosi 2014), ethnobotanical studies (Adjanohoun et al. 1996; Akabassi et al. 2017) and the physico-chemical properties of different part of $P$. nitida.

Plant species domestication program requires a deeper knowledge of the ecology and variability within the species. In addition, the valorization of NTFPs requires first a morphological characterization of their plant material. This description identifies interesting morphological characteristics according to the climate gradient and then those under the influence of environmental factors. There is lack of knowledge on the productivity of $P$. nitida according to climate zones and habitat. This information is necessary to identify, the environmental conditions favorable to a higher production of organs (fruits and seeds) and the role of habitat in the conservation and domestication of $P$. nitida.

In perspective to set up a sustainable conservation of the species in West Africa, the present study aims to (i) assess the influence of climate and habitat type on morphological variations and fruit production of $P$. nitida trees, (ii) assess the influence of soil physico-chemical characteristics on the distribution, morphological characteristics and fruit production of $P$. nitida trees. The hypotheses guiding these aims are (i) variability in tree morphological traits of $P$. nitida is more determined by climate than soil type, (ii) tree fruit production depends on environmental conditions, morphological characteristics and physicochemical characteristics of the soil.

\section{Material And Methods}

\section{Study areas}

The study was carried out in two West Africa climate zones, DG and GC (Fig. 1). In DG, Benin and Togo were considered. Both countries are more affected by the Dahomey Gap phenomenon. DG is the dry zone that separates the two forest blocks from tropical Africa (Bongers et al. 2004). The overall annual rainfall varies between $900-1400 \mathrm{~mm}$. The average temperature varies between 25 and $29^{\circ} \mathrm{C}$ with a relative humidity between 69 and $97 \%$. The vegetation is characterized by savanna that goes down to the coast with a mosaic of rain forest. There is also mangrove formations subject to tidal regimes (Akoegninou 1998). In the GC region of West Africa, Ivory Coast was considered. This area is located in the typical GC 
region with a rainfall of up to $2500 \mathrm{~mm}$ characterized by the presence of dense rain forests. The average temperature of GC varies between 23 and $29^{\circ} \mathrm{C}$ with a relative humidity between 65 and $98 \%$.

\section{Sampling}

The mating systems of the species were not yet clearly identified (Adjanohoun et al. 1996). However, it was more common in allogamous plants (Endress et al. 1996). Taking into account this information, and using stratified random sampling, individuals of $P$. nitida were collected by habitat types in each climatic zone. A distance of $100 \mathrm{~m}$ between individuals was considered using GPS (Global Positioning System) to avoid the collection of closely related individuals. Moreover, the individuals collected in the same climatic zone were consider to belong to the same population. The habitat types considered in this study were home garden, natural forest and botanical garden. A total of 132 individuals of the species were sampled (90 from DG and 42 from GC) across the study area. In DG, $P$. nitida were only collected in home gardens and botanical gardens because the species is absent in the wild (Akoegninou 1998; Akabassi et al. 2017) while in the GC zone in addition to the home garden and botanical garden, the $P$. nitida trees were also collected in natural forests.

\section{Data Collection}

Five tree's morphological traits were measured on each tree (The height $(\mathrm{H})$, circumference at $1.30 \mathrm{~m}$ (Cir), large crown diameter (LCD), small crown diameter (SCD) and number of branches from the first branch (NB)). In addition to this morphological traits, the fruit production (FP) was taken on each P. nitida individual. The age of the tree was also estimated with local population. Fruit production was estimated using the Extrapolation Counting method (Nacoulma 2012.). In addition, the major soil type (ferralitic soil of red color with sandy-clay texture) was identified using soil map of Willaime and Volkoff (Assogbadjo et al. 2012) and georeferenced coordinates were recorded for each P. nitida individual.

\section{Data analysis}

Principal Component Analysis (PCA) was performed to assess the relationship between morphological traits of the species and the climatic zones. The Pearson correlation was then calculated to explain the linear relationship that exists between the main components defined by the morphological parameters of trees and fruit production according to the two climatic zones. In order to identify the suitable habitat type of the species in each climatic zone, the Pearson correlation was also performed between the PCA axes and the habitat types. Georeferenced coordinates recorded were projected on the map of the Harmonized World Soil Database Version 1.2 database (FAO / IIASA / ISRIC / ISSCAS / JRC 2012) in order to determine on a smaller scale the granulometric variables of soil types on which individuals of the species were collected. The granulometric variables were \% clay, \% silt, \% sand and \% gravel. Organic carbon content (C), pH-water, and soils salinity were also identified.

\section{Results}




\section{Influence of climate on morphological variation and fruit production of $P$. nitida trees in West Africa}

The Principal Component Analysis (PCA) carried out on the dendrometric characteristics and fruit production of trees according to the two climatic zones revealed that the first two axes explained $65.35 \%$ of the total variation, which was sufficient to guarantee a precision of interpretation of morphological data. The first axis summarized $51.30 \%$ of the total variation data while the second axis summarized $14.05 \%$ of the total variation. Height, circumference, large and small crown diameter were strongly positively correlated with the first axis (Table 1a). Thus on the first axis, the high trees of $P$. nitida had big trunk and crown diameters. The number of branches was strongly positively correlated with the second axis. The Pearson correlation between the PCA axes, the fruit production and age of $P$. nitida trees indicated that the trees with big trunk and crown diameters were young with more branches with higher fruit production (Tables 1b).

Other result of the PCA indicated that high trees of $P$. nitida with big circumference, big crown diameters and more branches were observed in DG zone (Fig. 2).

The height of trees in the GC zone was slightly higher $(6.74 \pm 1.74 \mathrm{~m})$ than that of $D G(6.25 \pm 2.48 \mathrm{~m})$. The trees of DG had higher value of circumference $(47.60 \pm 22.75 \mathrm{~cm})$, crown diameter $(5.77 \pm 2.29 \mathrm{~m})$, fruit (99.35 \pm 175.03 fruits) and number of branches $(3.02 \pm 1.65)$ than the trees in the GC zone (Table 2).

Table 1a Correlation between the morphological variables, the PCA axes and the fruit production and age of $P$. nitida trees.

\begin{tabular}{lll}
\hline Variables & Axes 1 & Axes 2 \\
\hline H & 0,72 & $-0,30$ \\
Cir & 0,71 & $-0,20$ \\
GDH & 0,90 & $-0,03$ \\
PDH & 0,90 & $-0,01$ \\
NB & 0,45 & 0,87 \\
\hline
\end{tabular}

H: hauteur; Cir: circonférence ; GDH: Grand diamètre de houppier ; PDH: petit diamètre de houppier; NB: nombre de branches.

Table $1 \mathrm{~b}$ Corrélation entre les axes de l'ACP, la production fruitière et l'âge des arbres de $P$. nitida. 


\begin{tabular}{|lll|}
\hline & FP & Age \\
\hline FP & 1.00 & $0.30^{\star \star *}$ \\
\hline Age & $0.30^{\star \star *}$ & 1.00 \\
\hline
\end{tabular}

$\star \star \star ~ p<0.001 ; F P:$ production fruitière.

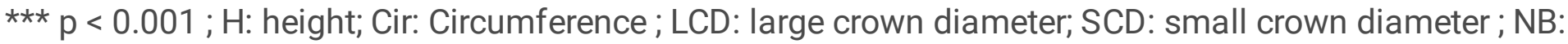
number of branching; FP: fruit production.

Table 2 Average values of morphological variables and the fruits production of $P$. nitida in both climatic zones.

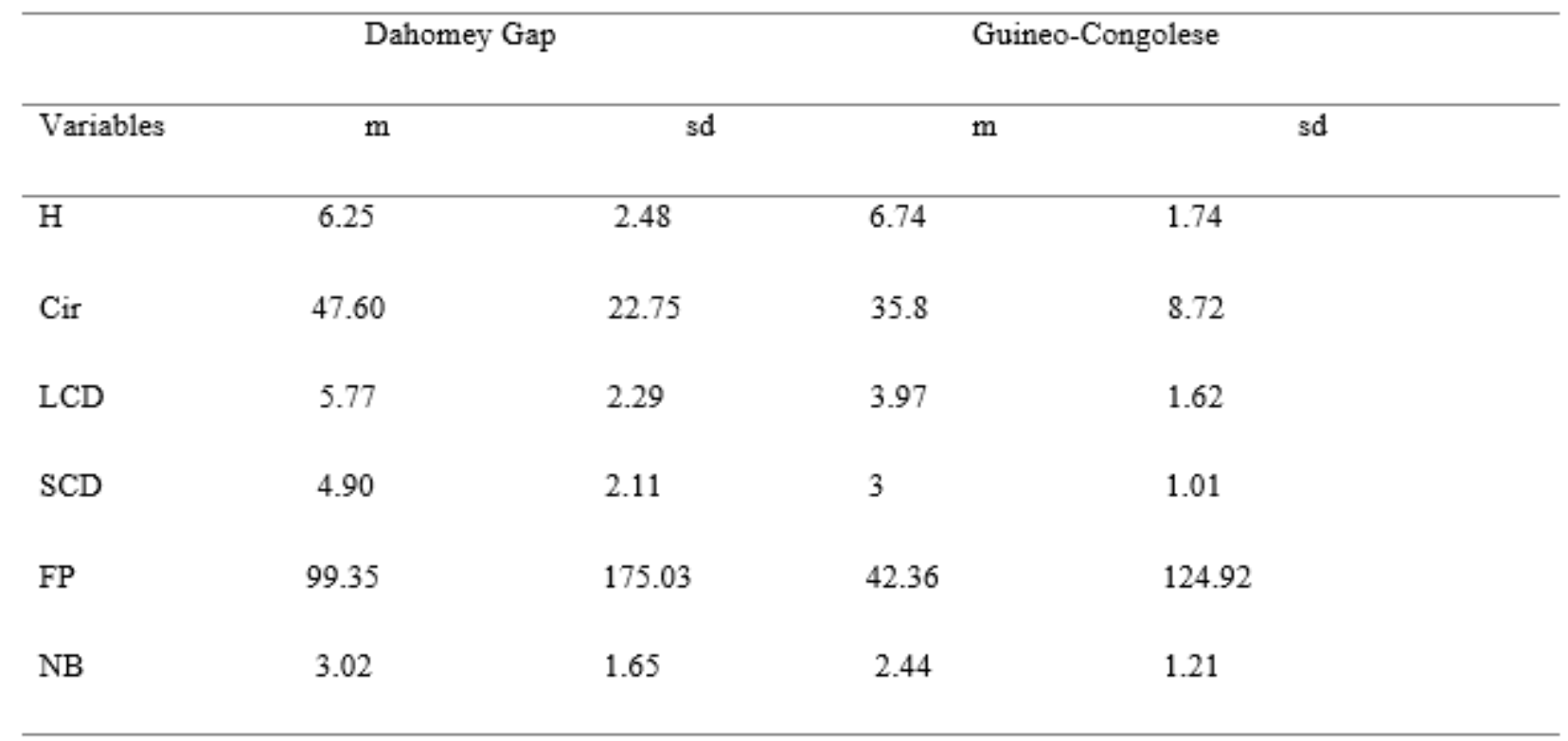

H: height; Cir: Circumference; LCD: large crown diameter; SCD: small crown diameter; NB: number of branching; FP: fruit production; m: mean; sd: standard deviation.

\section{Influence of habitat on morphological variation and fruit production of $P$. nitida trees in West Africa}

Projection of the habitat on the PCA axes showed that high trees of $P$. nitida with big circumference, big crown diameters and more branches were found in home gardens in both climatic zones (Fig. 3).

The height of the trees in natural forest was slightly higher $(7.07 \pm 1.59 \mathrm{~m})$ than that of the trees found in home gardens $(6.35 \pm 2.34 \mathrm{~m})$. While the trees in home gardens had highest values for the others variables (circumference, crown diameter, number of fruits and branches) (Table 3 ).

Type of major soil on which P. nitida was present in both climate zones (DG and GC) was ferralitic soil of red color with sandy-clay texture. On the smaller scale, we noticed that in DG region, $P$. nitida populations were found on two types of soil, namely Nitisols and Arenosols. In contrast, in GC region, populations of 
the species were present on Acrisols (Table 4). The pHs of these three soil types were acid and ranged from 5 to 5.3. The Organic Carbon content (Corg) of the three soil types was also substantially the same. Nitisols and Acrisols had four times more clay and two times more silty than Arenosols. In contrast, Arenosols had two times more sand than Nitisols and Arenosols. Overall, all soil types had the same salt content (Table 4).

Table 3 Mean values of morphological variables and fruits production of the trees according to the habitat types.

\begin{tabular}{llll}
\hline Variables & Hom_garden & Fo_natur & Bo_garden \\
\hline $\mathrm{H}$ & $6.35 \pm 2.34$ & $7.07 \pm 1.59$ & $6.50 \pm 1.55$ \\
$\mathrm{Cir}$ & $45.05 \pm 20.79$ & $31.72 \pm 4.05$ & $40.45 \pm 10.23$ \\
$\mathrm{LCD}$ & $2 \pm 1.29$ & $3.51 \pm 2$ \\
$\mathrm{SCD}$ & $5.5 \pm 2.11$ & $1.85 \pm 1.03$ & $3.3 \pm 1$ \\
$\mathrm{FP}$ & $4.53 \pm 1.97$ & $1.6 \pm 0.51$ & $25.72 \pm 51.34$ \\
$\mathrm{NB}$ & $88.90 \pm 168.25$ & $0.4 \pm 0.84$ & $2 \pm 1$ \\
\hline
\end{tabular}

H: height; Cir: Circumference; LCD: large crown diameter; SCD: small crown diameter; NB: number of branching; FP: fruit production; m: mean; sd: standard deviation; Hom_garden: Home garden; Fo_Natur: Natural forest; Bo_garden: Botanical garden.

Table 4 Physico-chemical properties of soils on which P. nitida populations were found in both climate zones. 


\begin{tabular}{|c|c|c|c|c|c|c|c|c|}
\hline Climate zones & Soil types & $\mathrm{pH}\left(\mathrm{H}_{2} \mathrm{O}\right)$ & Corg $(\%$ & 6) Clay (\% & \%) $\mathrm{Si}(\%$ & b) $\mathrm{S}(\%)$ & $\mathrm{Sa}(\mathrm{ECe})$ & (m) $\mathrm{Gr}(\%)$ \\
\hline \multirow[t]{4}{*}{ Dahomey Gap } & Nitisols & 5 & 0.69 & 32 & 28.5 & 39.5 & 0.1 & 18.5 \\
\hline & & $(0.07)$ & $(0,43)$ & $(12,73)$ & \multicolumn{2}{|c|}{$(6,36)(6,36)$} & $(0)$ & $(10.60)$ \\
\hline & \multirow[t]{2}{*}{ Arenosol } & 5.3 & 0.5 & 8 & 10.5 & 81.5 & 0.1 & 14.5 \\
\hline & & $(0.14)$ & $(0,27)$ & $(0)$ & $(0.70)$ & $(0.70)$ & $(0)$ & $(6,36)$ \\
\hline \multirow[t]{2}{*}{ Guineo-Congolaise } & e Acrisols & 5 & 0.69 & 32 & 24.5 & 47 & 0.1 & 21 \\
\hline & & $(0.07)$ & $(0.41)$ & $(9.9)$ & $(1.41)$ & \multicolumn{2}{|c|}{$(8.48)$} & $(2.83)$ \\
\hline
\end{tabular}

Si: Silt; S: Sand; Sa : Salinity; Gr: Gravel; Corg: Organic carbon.

\section{Discussion}

The results showed that morphological variables and fruit production varied significantly between the two climatic zones. The population of $P$. nitida in DG had higher values for most of the morphological variables considered as well as fruit production than GC population. However, when considering the habitat, $P$. nitida individuals have the similar morphological variation and fruit production in home garden in both climatic zones that is different with the species morphology in natural forest or botanical garden. Thus, the difference between the two climatic zones may be related to the habitat. The individuals from DG were collected in home gardens and botanical gardens while those of the GC zone were collected in natural forest addition to home garden and botanical garden.

In home gardens in both climatic zones, trees of $P$. nitida were bigger with large crown diameters, more branches and fruit production while the height of the trees in natural forest was slightly higher than that of the trees found in home gardens (Table 3). This difference could be attributed to the total decrease of photosynthesis and carbon fixation of trees in natural forest (Martın et al. 2015). P. nitida is an understorey with a maximum height of $35 \mathrm{~m}$ (Adjanohoun et al. 1996). Thus, in forest, it may be affected by light competition for photosynthesis. These results corroborated with those of Fandohan et al. (2009) on Tamarindus indica and Shackleton et al. (2003) on Sclerocarya birrea who explained that the tallest trees with low diameter found in gallery forests were a possible result of higher competition for light.

Moreover, correlation of fruit production with tree morphological traits indicated that the youngest individuals had more branches with higher fruit production in contrast with the old trees. This could be 
explained by the fact that the old trees may have reached their cruising production year. Each type of fruit tree has its age of maturity from which it begins to bear fruit and another age from which it reaches its cruising production (AFRISTAT 2001). Moreover, a decreasing tree growth and productivity over time could probably be attributed to variations in the supply rate of required resources (light, nutrients and water), changing balance between photosynthesis and respiration, increased hydraulic resistance, decreased nutrient supply, or genetic changes with meristem age (Day et al. 2001). Our results corroborated with those of Kutsch et al. (2009) who found that the productions of fruit trees decrease over time. The decrease in production was remained below $2 \%$ until the age of about 100 years, after which it reached the level of about $5 \%$ by the age of 200 years. This suggests that branch senescence decreases as the tree grows older and becomes less dense.

Preferred soils of $P$. nitida in DG were Nitisols and Arenosols. Previous studies in Benin (DG) showed that the frequency of $P$. nitida was high on Nitisols than Arenosols (Akabassi et al. 2017). Nitisols in DG and Acrisols in GC had almost similar physico-chemical characteristics (Table 4). This result confirmed that the difference between the morphological variables and the fruits production of the trees in both climatic zones may not be related to the soil but to the habitat types. The light would certainly have an influence on the trees morphology. Moreover, the significant difference between the individuals found in forest and those in home gardens confirmed that $P$. nitida is a heliophilous species that required more light. Some studies dealing with different plant species already reported that out of genetic factors, morphological variation of NTFPs were low on the soils with the same physico-chemical characteristics but vary with and ecological gradients (Assogbadjo et al. 2013; Chadare et al. 2009).

\section{Implication for conservation and sustainable management}

This study revealed how climate and habitat influenced the morphology and production of $P$. nitida. Results can serve as a springboard to investigate the climate gradient effect on the evolutionary history of $P$. nitida populations in West Africa. It could be important to infer ancestral states of climatic zone preferences of the species. In forest, $P$. nitida had low fruit production, whereas in home gardens, fruit production is high. Thus light is an important factors for the species. This could be taken into account in the conservation and production policy of the species.

Habitat types and age of trees could significantly decreased the quantity and quality of fruits and seeds, which could compromise the chances of natural regeneration of this multipurpose tree species in the long-term. The fact that $P$. nitida requires more light, its conservation and production must take into account open spaces.

This study represent an important step towards understanding the role of climate and habitats in the conservation and production of $P$. nitida.

\section{Conclusion}


The study provides the effect of climate and habitat on morphological characteristics and fruit production of $P$. nitida. High trees of $P$. nitida with large circumference and crown diameters, more branches and fruits were observed in home garden. The habitat types and tree age influenced significantly the morphological variables and fruit production of $P$. nitida. Moreover, $P$. nitida population preferred open habitat with an acid soil. Home gardens provide a springboard for the conservation and sustainable management of $P$. nitida.

\section{Declarations}

\section{Acknowledgements}

Our honest thanks to "Centre d'Excellence Africain sur les Changements Climatiques, la Biodiversité et I'Agriculture Durable (CEA-CCBAD)" of Côte d'Ivoire which took charge of the field works.

\section{References}

1. Adomou, A. (2005). Vegetation patterns and environmental gradients in Benin: implications for biogeography and conservation, PhD Thesis, Wageningen University, the Netherlands. 135 p. ISBN 90-8504-308-5.

2. Adjanohoun, J.E., Aboubakar, N., Dramane, K., Ebot, M.E., Ekpere, J.A., Enow-Orock, E.G., Focho, D., Gbile, Z.O., Kamanyi, A., \& Kamsu-Kom, J. (1996). Traditional medicine and pharmacopoeia: contribution to ethnobotanical and floristic studies in Cameroon. OUA/STRC, Lagos, 301.

3. AFRISTAT (2001) Enquête test sur l'estimation de la production fruitière. Rapport finale, 146.

4. Aguwa, C.N., Ukwe, C.V., Inya-Agha, S.I., \& Okonta, J.M. (2001). Antidiabetic effect of Picralima nitida aqueous seed extract in experimental rabbit model. Journal of Natural Remedies 1, 135-139.

5. Akabassi, G.C., Padonou, E.A., Chadare, F.J., \& Assogbadjo, A.E. (2017). Importance ethnobotanique et valeur d'usage de Picralima nitida (stapf) au Sud-Bénin (Afrique de l'Ouest). International Journal of Biological and Chemical Sciences 11, 1979-1993.

6. Akoegninou, A. (1998). Les forêts denses humides semi-décidues du Sud-Benin. Journal de la Recherche Scientifique de l'Université de Lomé 2, 125-31.

7. Akpagana, K, Kudzo, A. G., Koami, A. (1994). Espèces d'Angiospermes nouvelles pour la flore du Togo, Acta Botanica Gallica, 141:6-7, 781-787.

8. Assogbadjo, A.E., Chadare, F.J., Kakaï, R.G., Fandohan, B., \& Baidu-Forson, J.J. (2012). Variation in biochemical composition of baobab (Adansonia digitata) pulp, leaves and seeds in relation to soil types and tree provenances. Agriculture, Ecosystems \& Environment 157, 94-99.

9. Betti J.L. (2004.): An ethnobotanical study of medicinal plants among the Baka pygmies in the Dja biosphere reserve, Cameroon.

10. Bickii, J., Tchouya, G.R.F., Tchouankeu, J.C., \& Tsamo, E. (2007). Antimalarial activity in crude extracts of some Cameroonian medicinal plants. African Journal of Traditional, Complementary and 
Alternative Medicines 4, 107-111.

11. Bongers, F., Poorter, L., \& Hawthorne, W.D. (2004). The forests of Upper Guinea: gradients in large species composition, in: Biodiversity of West African Forests. An Ecological Atlas of Woody Plant Species. CABI, 41-52.

12. Chadare, F.J., Hounhouigan, J.D., Linnemann, A.R., Nout, M.J.R., van Boekel, M.A.J.S. (2008). Indigenous knowledge and processing of Adansonia digitata L. food products in Benin. Ecol. Food Nutr. 47, 338-362.

13. Chadare, F.J., Linnemann, A.R., Hounhouigan, J.D., Nout, M.J.R., \& Van Boekel, M. (2009). Baobab food products: a review on their composition and nutritional value. Critical Reviews in Food Science and Nutrition 49, 254-274.

14. Church, R.J., 1966, West Africa: a study of the environment and of man's use of it: Longman's, Green and Co., Ltd.

15. Day, M.E., Greenwood, M.S., White, A.S. (2001). Age-related changes in foliar morphology and physiology in red spruce and their influence on declining photosynthetic rates and productivity with tree age. Tree Physiology 21:1195-1204.

16. Dhillion, S.S., Gustad, G. (2004). Local management practices influence the viability of the baobab (Adansonia digitata Linn.) in different land use types, Cinzana, Mali. Agric Ecosyst Environ 101:85103.

17. Endress, M.E., Sennblad, B., Nilsson, S., Civeyrel, L., Chase, M., Huysmans, S., Grafström, E., \& Bremer, B. (1996). A phylogenetic analysis of Apocynaceae s. str. and some related taxa in Gentianales. A multidisciplinary approach. Opera Botanica Belgica 7, 59-102.

18. Erharuyi, O., Falodun, A., \& Langer, P. (2014). Medicinal uses, phytochemistry and pharmacology of Picralima nitida (Apocynaceae) in tropical diseases: A review. Asian Pacific Journal of Tropical medicine 7, 1-8.

19. Fandohan, A B., Assogbadjo, A. E., Glele Kakaï, R. L., Sinsin, B., Van Damme P. (2009). Impact of habitat type on the conservation status of tamarind (Tamarindus indica L.) populations in the W National Park of Benin. Fruits 65, 11-19.

20. Gaoue, O.G., Ticktin, T. (2008). Impacts of bark and foliage harvest on Khaya senegalensis (Meliaceae) reproductive performance in Benin. J Appl Ecol 45, 34-40.

21. Gbadamosi, A.E. (2014). Effect of Watering Regimes and Water Quantity on the Early Seedling Growth of Picralima nitida (Stapf). Sustainable Agriculture Research 3, 35-43.

22. Holaly, G.E., Simplice, K.D., Charlemagne, G., Kodjovi, A., Kokou, A., Tchadjobo, T., Amegnona, A., Komlan, B., \& Jacques, S. (2015). Étude ethnobotanique des plantes utilisées dans le traitement du diabète dans la médecine traditionnelle de la région Maritime du Togo. The Pan African Medical Journal 20, 437.

23. Idohou, R., Fandohan, B., Salako, V.K., Kassa, B., Gbèdomon, R.C., Yédomonhan, H., Glèlè Kakaï, R.L., \& Assogbadjo, A.E. (2014). Biodiversity conservation in home gardens: traditional knowledge, use 
patterns and implications for management. International Journal of Biodiversity Science, Ecosystem Services \& Management 10, 89-100.

24. Jamieson, M.A., Trowbridge, A.M., Raffa, K.F., \& Lindroth, R.L. (2012). Consequences of climate warming and altered precipitation patterns for plant-insect and multitrophic interactions. Plant Physiology 160, 1719-1727.

25. Kutsch, W. L., Wirth, C., Kattge, J.,, Nollert, S., Herbst, M., Kappen, L. (2009). Ecophysiological Characteristics of Mature Trees and Stands - Consequences for Old-Growth Forest Productivity. Ecological Studies 207, 57-79.

26. Martın, D., Vazquez-Pique, J., Alejano, R. (2015). Effect of pruning and soil treatments on stem growth of holm oak in open woodland forests. Agroforestry Systems 89, 599-609.

27. Matig, O.E., Ndoye, O., Kengue, J., \& Awono, A. (2006). Les fruitiers forestiers comestibles du Cameroun. Bioversity International. International Plant Genetic Resources Institute, 220p.

28. Miller, C.S., \& Gosling, W.D. (2014). Quaternary forest associations in lowland tropical West Africa. Quaternary Science Reviews 84, 7-25.

29. Nacoulma, B.M.I., 2012. Dynamique et stratégies de conservation de la végétation et de la phytodiversité du complexe écologique du parc national du W du Burkina Faso (PhD Thesis). Thèse de doctorat, Université de Ouagadougou. 153p.

30. Nacoulma, B. M. I., Traore, S., Sinsin, B., Lykke, A. M., Thiombiano, A. (2016). Impact of bark and foliage harvesting on fruit production of the multipurpose tree Afzelia africana in Burkina Faso (West Africa). Agroforest Systems. DOI 10.1007/s10457-016-9960-9.

31. Neuenschwander, P., Sinsin, B., \& Goergen, G. (2011). Protection de la Nature en Afrique de l'Ouest: Une Liste Rouge pour le Bénin Nature Conservation in West Africa: Red List for Benin. Ibadan: ITTA.

32. Ouédraogo-Koné, S., Kaboré-Zoungrana, C.Y., Ledin, I. (2006). Behaviour of goats, sheep and cattle on natural pasture in the sub-humid zone of West Africa. Livers Sci 105:244-252.

33. Parmesan, C. (2006). Ecological and evolutionary responses to recent climate change. Annu. Rev. Ecol. Evol. Syst. 37, 637-669.

34. Salako, V.K., Fandohan, B., Kassa, B., Assogbadjo, A.E., Idohou, A.F.R., Gbedomon, R.C., Chakeredza, S., Dulloo, M.E., \& Kakaï, R.G. (2014). Home gardens: an assessment of their biodiversity and potential contribution to conservation of threatened species and crop wild relatives in Benin. Genetic Resources and Crop Evolution 61, 313-330.

35. Shackleton, C.M., Botha J., Emanuel, P.L. (2003). Productivity and abundance of Sclerocarya birrea caffra in and around rural settlements and protected area of the bushbuckridge lowed, South Africa, Forest Trees Livelihoods 13, 217-232.

36. Teugwa, C.M., Mejiato, P.C., Zofou, D., Tchinda, B.T., \& Boyom, F.F. (2013). Antioxidant and antidiabetic profiles of two African medicinal plants: Picralima nitida (Apocynaceae) and Sonchus oleraceus (Asteraceae). BMC Complementary and Alternative Medicine 13, 175.

37. Vanninen, P., Ylitalo, H., Sievanen, R., Makela, A. (1996). Effects of age and site quality on the distribution of biomass in Scots pine (Pinus sylvestris $L$ ). Trees Structure Function 10:231-238 
38. Willaime, P., Volkoff, B. (1967). Carte pédologique du Dahomey à l'echelle de 1: 1000 000. Office de la recherche scientifique et technique outre-mer. Centre de Cotonou.

39. Yakeu: Local knowledge and socio-economic values of Picralima nitida ((stapf) th. \& H. Durand) in the humid forest zone of Cameroon. M.Sc. thesis, Faculty of Bioscience Engineering, Ghent University, Belgium, 2012; 94.

\section{Figures}

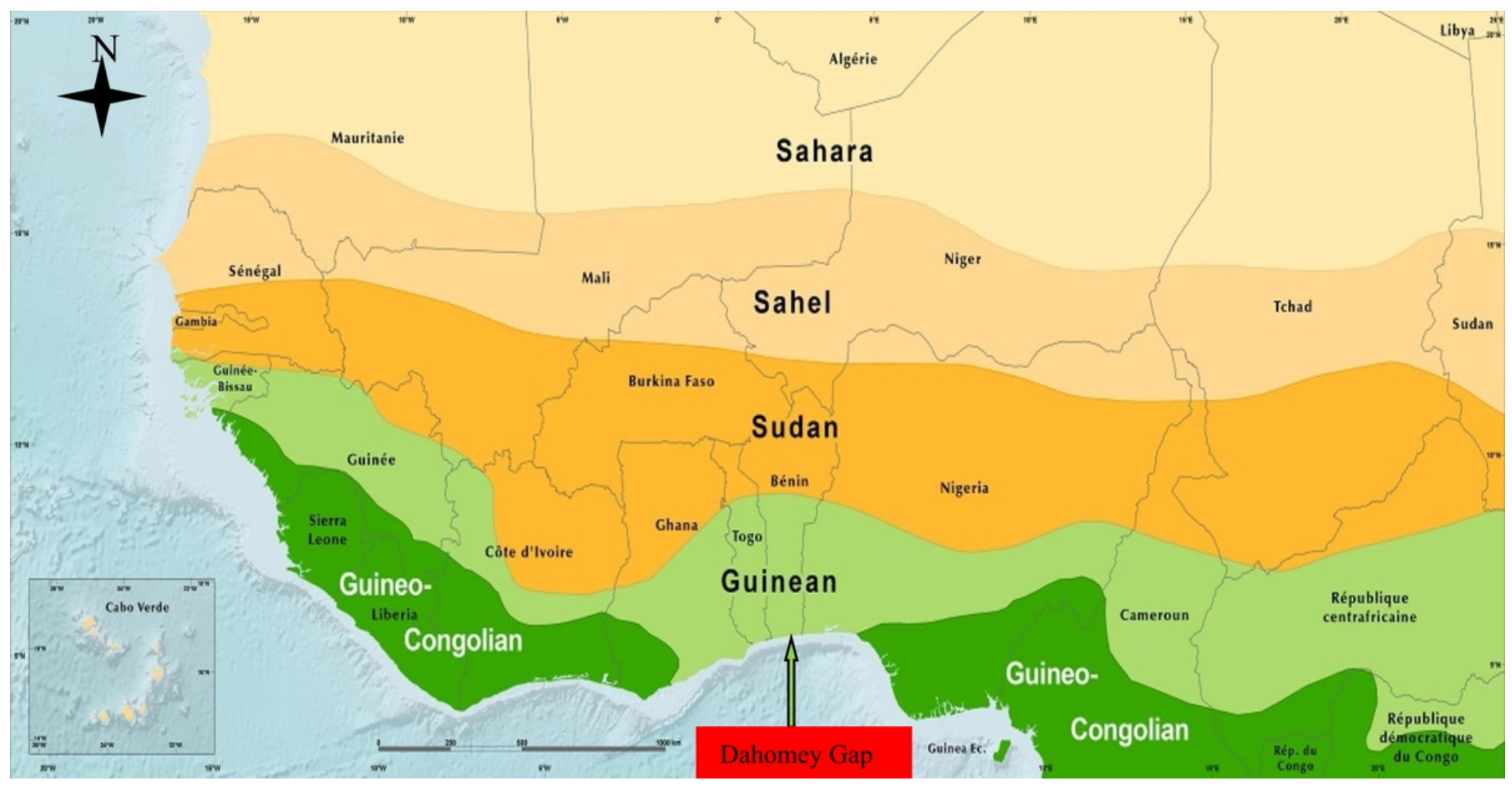

\section{Figure 1}

Guineo-Congolese region and Dahomey Gap (Church, 1966). 


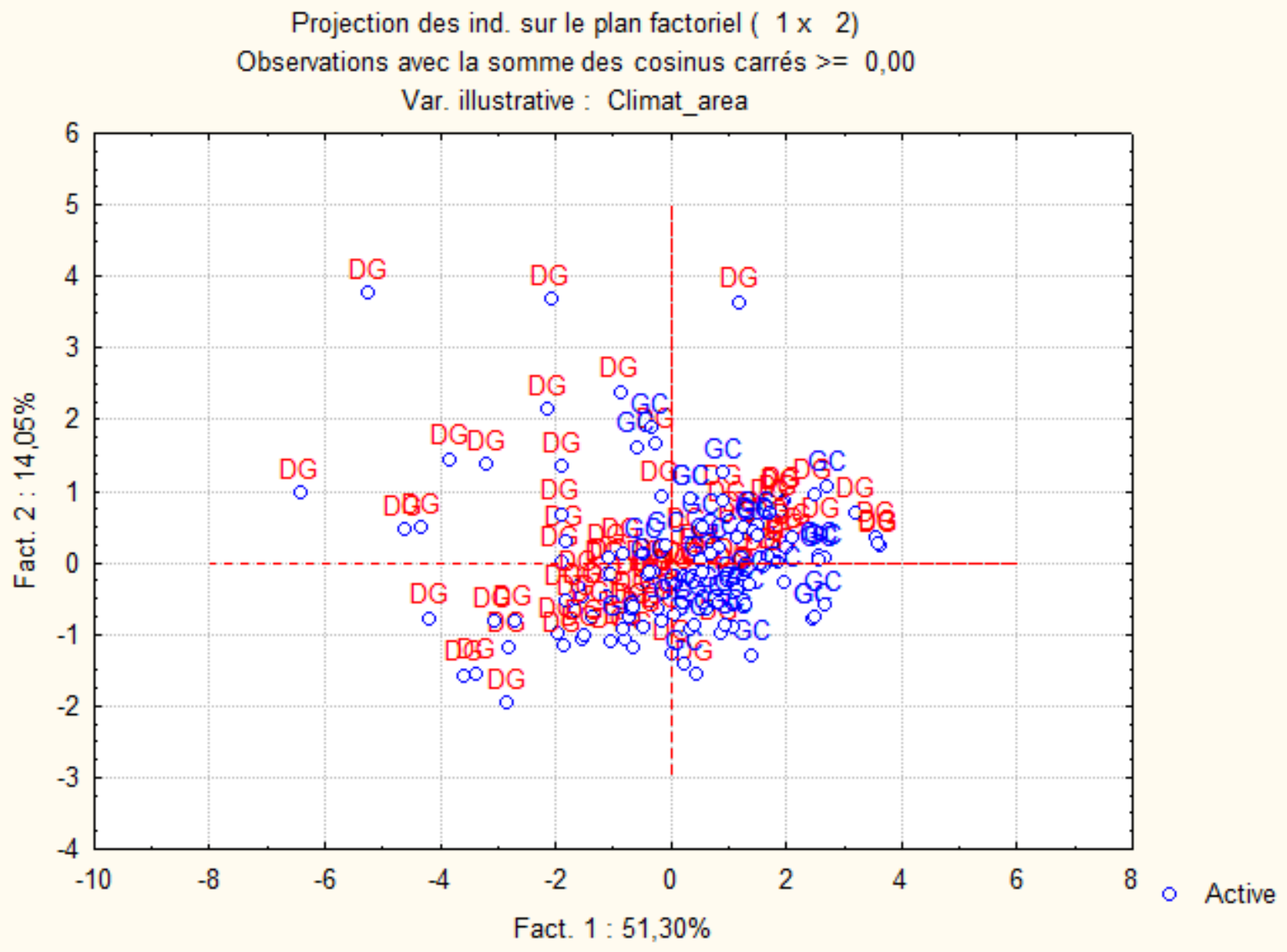

Figure 2

Projection of the climate zones on the PCA axes. DG: Dahomey Gap; GC: Guinean-Congolese. 


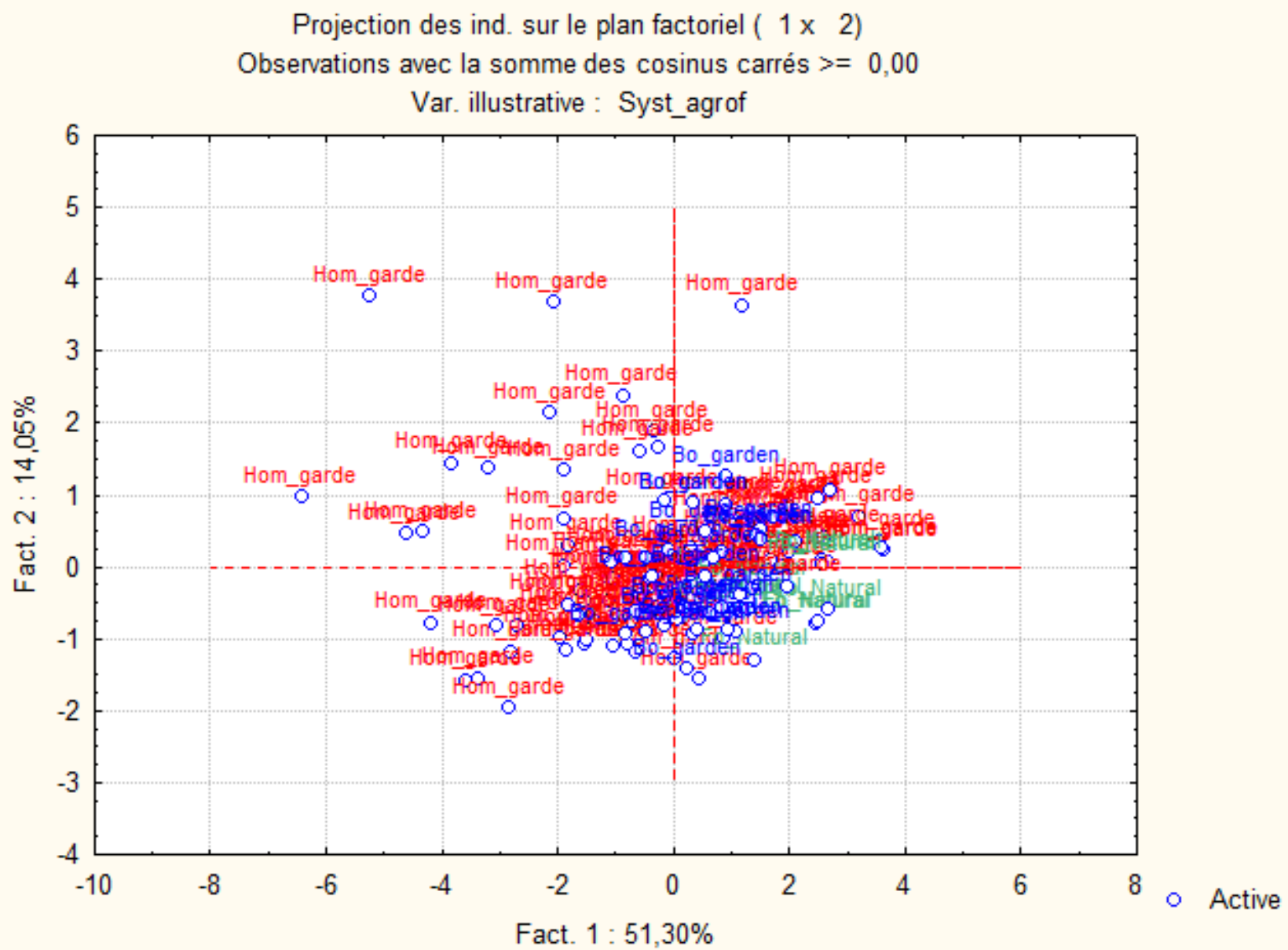

\section{Figure 3}

Projection of the agroforestry system on the PCA axes. Hom_gard: Home garden; Fo_Natur: Natural forest; Bo_garde: Botanical garden. 